\title{
Seismically-triggered organic-rich layers in recent sediments from Göllüköy Lake (North Anatolian Fault, Turkey)
}

\author{
Ulaş Avşar $^{\mathrm{a}, \mathrm{b}}$, Aurélia Hubert-Ferrari ${ }^{\mathrm{c}}$, Marc De Batist ${ }^{\mathrm{a}}$, Gilles Lepoint ${ }^{\mathrm{d}}$, Sabine Schmidt ${ }^{\mathrm{e}}$, Nathalie Fagel ${ }^{\mathrm{f}}$ \\ ${ }^{a}$ Renard Centre of Marine Geology (RCMG), Ghent University, Krijgslaan 281, 9000 Gent, Belgium \\ ${ }^{\mathrm{b}}$ Division of Physical Sciences and Engineering, King Abdullah University of Science and Technology \\ (KAUST), 23955-6900 Thuwal, Kingdom of Saudi Arabia \\ ${ }^{c}$ Unit of Physical and Quaternary Geography, University of Liège, Sart Tilman, B- 4000 Liège, Belgium \\ ${ }^{\mathrm{d}}$ Laboratory of Oceanology - MARE Center, University of Liège, Sart Tilman, B- 4000 Liège, Belgium \\ ${ }^{\mathrm{e}}$ UMR 5805 EPOC OASU, University of Bordeaux, 33405 Talence Cedex, France \\ ${ }^{\mathrm{f}}$ Department of Geology, University of Liège, Sart Tilman, B- 4000 Liège, Belgium
}

\begin{abstract}
Multi-proxy analyses on the sedimentary sequence of Göllüköy Lake, which is located on the eastern North Anatolian Fault (NAF), reveals a complete and high-resolution paleoseismic record for the last 650 years. Six sedimentary events are detected in a $3.1 \mathrm{~m}$-long piston core. They form distinct organic-rich intercalations within the background sedimentation, which are characterized by strong anomalies on the loss-on-ignition (LOI) and total organic carbon (TOC) profiles, as well as by lighter colours on the X-ray radiographic images. Itrax microXRF core scanner data are also used to contribute to the detection and characterization of the event deposits. After the detection of the sedimentary events, their temporal correlation with the earthquakes in the historical seismicity catalogue of the NAF is tested. The youngest event is dated to 1940 s by using ${ }^{210} \mathrm{~Pb}$ and ${ }^{137} \mathrm{Cs}$ profiles in sediment, which coincides with the 1939 earthquake $\left(\mathrm{M}_{\mathrm{s}}=7.7\right)$ on the NAF. The ages of the older five events are determined based on radiocarbon dating and regional time-stratigraphic correlation. Radiocarbon dating on the bulk sediment samples does not provide reliable results due to hard-water effect. On the other hand, dating on charcoals, Ephippia of Daphnia and phragmite remains significantly improves the results and implies a mean sedimentation rate of $0.28 \mathrm{~cm} / \mathrm{yr}$. Based on this preliminary sedimentation rate, we show that organic matter content variations through our record correlates with the varve-based $\delta^{18} \mathrm{O}$ record of Nar Lake, which is located $350 \mathrm{~km}$ southwest of Göllüköy Lake. Accordingly, high-precipitation/low-evaporation climatic episodes detected in Nar Lake are represented by higher organic matter content in Göllüköy sediments. Fine-tuning the Göllüköy LOI record to the Nar $\delta^{18} \mathrm{O}$ record reveals that the ages of the sedimentary events in Göllüköy match with well-known historical earthquakes that occurred around the lake. Finally, the origin of the organic-rich intercalations is discussed based on macroscopic observations and organic geochemistry. The events are attributed to reworked organic matter eroded from the lake's littoral zone by seismically-induced water oscillations (seiche), and their subsequent deposition at the middle parts of the lake. These seismically-induced events are atypical compared to the classic earthquake-triggered sedimentary processes in lacustrine environments, which are shortly reviewed in order to emphasize the unusual Göllüköy Lake record.
\end{abstract}

Keywords: Göllüköy Lake, lacustrine paleoseismology, the North Anatolian Fault, radiochronology, timestratigraphic correlation, Nar Lake, principle component analysis, ephippia of Daphnia, seiche

\section{Introduction}

Determination of characteristic recurrence intervals for certain earthquake magnitudes is the main goal of seismic hazard assessment studies. In order to achieve this goal, modern seismic hazard assessment analyses use input parameters mainly based on instrumentally recorded timing, epicentral location and magnitude of earthquakes, and geodetically measured slip rates on faults. However, these input parameters have been measured with high spatiotemporal accuracy only for the last few decades, an observation period much shorter than the recurrence interval of most faults (Yeats and Prentice, 1996). Given that slip rate and micro-seismic activity of a fault may not be constant through its seismic cycle (e.g., King and Bowman, 2003; Chevalier et al., 2005), the short observation period of these input parameters limits reliable evaluation of long-term seismic patterns. Hence, paleoseismic data spanning at least several seismic cycles becomes crucial to improve the outcomes of seismic hazard assessment analyses.

Even though the data provided by paleoseismic investigations cannot offer the spatiotemporal and physical (e.g., magnitude) accuracy of instrumental records, they still provide valuable information to understand the long-term patterns of seismicity. The main technique in paleoseismology is on-fault trenching (McCalpin, 2009). Its basic motivation is to detect the stratigraphical event horizons within fault-related sedimentary sequences and to 
estimate their age. This technique provides spatially precise data in terms of the evidence of surface rupturing at a specific point on the fault. However, errors on the event ages are relatively large due to the difficulties in understanding the relationship between the dated samples and their deposits, and the methodological uncertainties of dating techniques (Fraser et al., 2010). In addition, this technique is not applicable on blind (i.e., reverse or trust) and offshore faults, yet the largest known earthquakes are commonly related to this type of tectonic structures (Caputo and Helly, 2008). In this context, subaqueous paleoseismology, which can also detect far-field effects of earthquakes, has significantly gained popularity in recent years.

Paleoearthquakes can be traced as sedimentary events in lacustrine or marine sedimentary sequences, although sedimentary events in these environments can be caused by mechanisms other than seismicity (e.g., climatic, anthropogenic and flooding events). In general, assigning a seismic triggering mechanism to sedimentary events observed in marine or lacustrine sequences requires temporal validation with historical seismicity records, and this can be achieved only by establishing precise sediment chronologies. The present study illustrates the discovery of new type of lacustrine seismites by establishing a precise sedimentary event chronology and its temporal validation with the historical seismicity records. We focus on the complete sedimentary infill of a small sink-hole pond, Göllüköy Lake, located a few kilometres apart from a major active fault in Turkey, the North Anatolian Fault (NAF). The region has well-acknowledged historical seismicity records (e.g., Ambraseys, 2009), which is extremely important to validate the seismic origin of the detected sedimentary events. The chronology of the sediments is based on ${ }^{210} \mathrm{~Pb}$ and ${ }^{137} \mathrm{Cs}$ dating, radiocarbon dating on different organic fractions and timestratigraphic correlation of the Göllüköy Lake record with the varve-based $\delta^{18} \mathrm{O}$ record of Nar Lake (Jones et al., 2006). Our study also presents a brief review of seismically-induced sedimentary processes in lacustrine environments in order to emphasize the atypical sedimentary events in the Göllüköy Lake record.

\section{Earthquake sedimentary records in lacustrine environments}

Lacustrine sedimentary traces of earthquakes reported in the literature are summarized and illustrated as a stratigraphical columnar section in Figure 1 (Avşar, 2013). Consequences of earthquakes on sedimentation are subdivided into two main groups based on timing: i.e. effects on already deposited sediments (co-seismic and immediate post-seismic) and on subsequent sedimentation (long-term post-seismic).

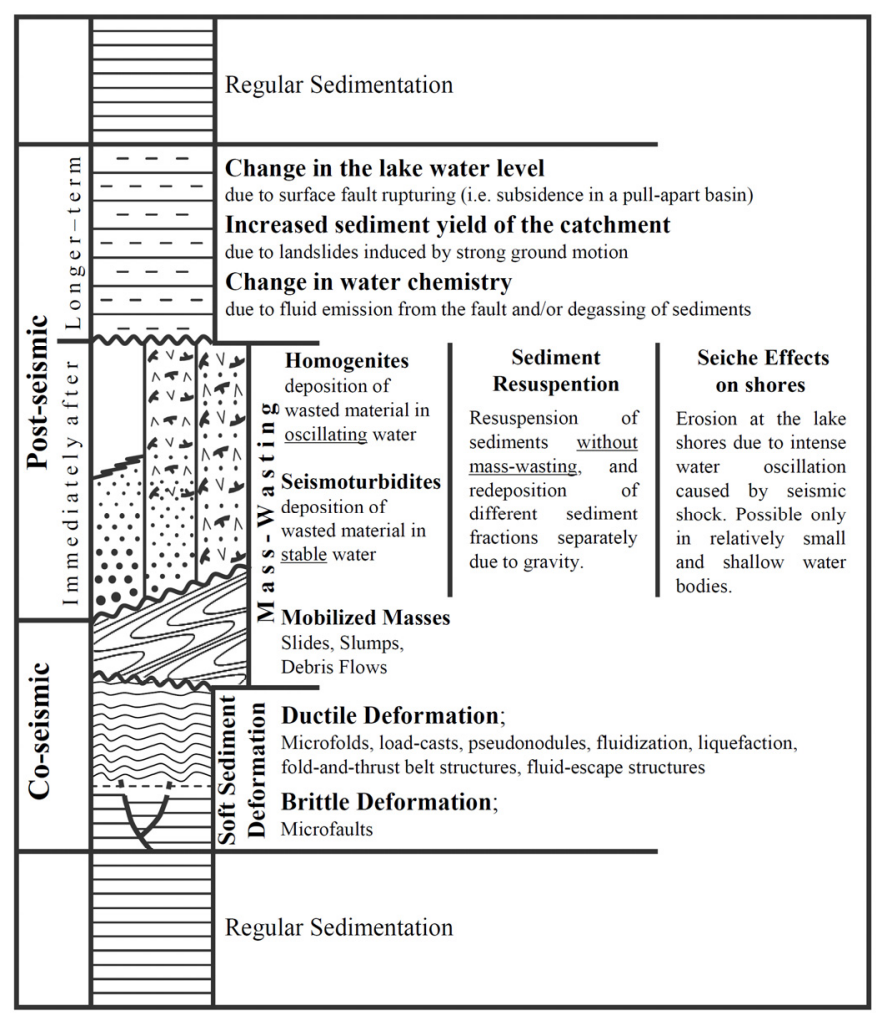

Figure 1. Stratigraphical columnar section schematizing lacustrine sedimentary traces of earthquakes, compiled from the investigations on 51 lakes in the lacustrine paleoseismology literature (Avşar, 2013). 
Co-seismic and short-term post-seismic effects comprise in-situ soft sediment deformations, mass-wasting events, sediment resuspension, and seiche effects on shores. Depending on the compaction level of sediments and the strength of the cyclic loading, in-situ soft sediment deformation processes take place in terms of either brittle or ductile deformation or both. At a certain depth from the water-sediment interface, where sediments are compacted enough, brittle deformation can be observed in terms of microfaults (e.g., Seilacher, 1969; Monecke et al., 2004; 2006; Beck, 2009). On the other hand, in less-consolidated sediments, which are closer to the watersediment interface, cyclic loading may result in ductile deformations like microfolds (Monecke et al., 2004), loadcasts (Sims, 1973; Hibsch et al., 1997; Moretti and Sabato, 2007), pseudonodules (Sims, 1973; Migowski et al., 2004; Monecke et al., 2004) and liquefaction/fluidization/fluid-escape structures (Lignier et al., 1998; Chapron et al., 2004; Moernaut et al., 2007; 2009; Beck, 2009). In order to assign a seismic triggering mechanism to in-situ soft sediment deformations, researchers often seek for coeval occurrence of deformations at different locations in the lake basin (e.g., Becker et al., 2005; Monecke et al., 2004; Kagan et al., 2011) and temporal correlation of these deformations with known historical earthquakes (Fanetti et al., 2008; Beck, 2009).

The most commonly observed seismically-induced process in lacustrine environments is mass-wasting (e.g., Chapron et al., 1999; Karlin et al., 2004; Schnellmann et al., 2006; Moernaut et al., 2007; 2014; Waldmann et al., 2011). Seismic shaking may trigger sedimentary instabilities at steep slopes of lake basins. These instabilities result in mobilized masses at proximal sites (i.e., slides, slumps, debris flows) and deposition from induced turbidity currents at distal sites (i.e., seismoturbidites or homogenites). Unlike the typical fining-upward deposition of turbidites under stable water conditions, seismically-induced water oscillation (i.e., seiche) may keep fine-grained fraction of the resuspended sediment further in suspension. This fine-grained fraction forms "homogenites" after oscillation ceases (e.g., Chapron et al., 1999; Monecke et al., 2006; Bertrand et al., 2008; Beck, 2009). However, mass failures and related turbidity currents do not necessarily have to be of seismic origin. Routine overloading and oversteepening of subaqueous slopes, loading by storm waves, severe lake level variations and extreme flooding events can trigger mass failures as well. Non-seismic shallow-water triggering mechanisms (i.e., storm wave action and lake level variations) can be ruled out if mass failures occur at sites deeper than the maximum wavebase depth and typical spatial extent of lake fluctuations. Mass failures on different slopes of various orientations and at different water depths are also unlikely to occur coevally. If coevality of multiple mass failures is the case, non-seismic triggering due to routine overloading and oversteepening can be ruled out as well (e.g., Schnellmann et al., 2006; Guyard et al., 2007; Moernaut et al., 2007; Waldmann et al., 2011).

Co-seismic sediment resuspension does not have to be of mass-wasting origin. Earthquake-induced water oscillations or seiche may cause resuspension of sediments from the steepening parts of the lake basin. These resuspended sediments, generally organic rich, are deposited at distal parts of lakes with a gravitational segregation of the clastic and organic fractions; e.g. silt layer overlain by organic rich layer (Siegenthaler et al., 1987; Doig, 1990; 1991; 1998a; 1998b). This mechanism is probably limited to environments having almost clay-free deposits because cohesive clayey-mud is unlikely to be resuspended by water oscillations.

As it is illustrated by the present study, seismically-induced water oscillations may lead erosion at the shores of small and shallow water bodies, and leave basin-wide sedimentary traces. The details of this process are explained in the results and discussions section.

Earthquakes may result in relatively long term effects, which can be traced in post-seismic sedimentation. Earthquake-induced landslides will increase sediment yield in drainage basins (Keefer, 1984; 1999), and hence sediment influx to lake basins. Besides the historical eye witnesses of muddy rivers after earthquakes (e.g. after the 1663 Charlevoix and 1679 Erivan earthquakes mentioned in Doig (1986) and Ambraseys and Finkel (1995), respectively), possible increase in sediment yield by earthquake-induced landslides is further evidenced by quantitative analyses of the suspended load of rivers before and after the 1999 Chi-Chi earthquake (Dadson et al., 2004; Lin et al., 2008; Chuang et al., 2009). More recently, Avşar (2014) reported similar observations related to three earthquakes in Turkey; the 1998 Adana-Ceyhan Earthquake ( $\mathrm{Mw}=6.2)$, the 1999 İzmit $(\mathrm{Mw}=7.4)$ and Düzce $(\mathrm{Mw}=7.2)$ earthquakes. This kind of change in sediment influx can be observed in lacustrine sedimentary sequences in terms of increase in sedimentation rates, content of clastic fraction, sediment density and mean grain-size (e.g., Doig, 1986; 1990; Boes et al., 2010; Howarth et al., 2012; Hubert-Ferrari et al., 2012; Avşar et al., 2014).

Consequences of co-seismic subsidence on post-seismic sedimentation have been successfully illustrated in many coastal zones (e.g., Atwater, 1987; Atwater et al., 2001; Hayward et al., 2006; Shennan and Hamilton, 2006; Nelson et al., 2008). In the case of lakes located in tectonically controlled basins (i.e., in a pull-apart basin), co-seismic subsidence may result in deepening of the lake and sudden inundation of surrounding land to some extent. Alternating peat and mud layers in lacustrine sedimentary sequences can be attributed to successive basin subsidence and submergence of peats in the littoral zone. Effects of co-seismic subsidence on sedimentation can be further investigated through taxonomical and biogeochemical analyses on diatom, 
foraminifera, pollen and organic matter contents. For example, proportional changes in benthic versus planktonic species and terrestrial versus lacustrine origin of organic matter can provide valuable information to trace evidences of tectonic subsidence in lake basins (e.g., Mirecki, 1996; Leroy et al., 2009; 2010; Vologina et al., 2010; Bertrand et al., 2011).

Numerous historical records and eye witnesses report earthquake-related fluid emissions from faults (mostly new springs). For example, new springs opened up near the shores of Dead Sea about one week before the 1943 Earthquake and disgorged white material into the Sea for about 5 months. Although Ben-Menahem (1976) clearly illustrates white layers in the sediments of Dead Sea and interprets them as sedimentary records of paleoseismic events, this kind of observations are rare in the available literature.

\section{The Study Area}

Göllüköy Lake ( $40^{\circ} 22^{\prime} 40^{\prime \prime} \mathrm{N}, 37^{\circ} 28^{\prime} 00^{\prime \prime} \mathrm{E} ; 1042 \mathrm{~m}$ asl.) is located on the eastern part of the North Anatolian Fault (NAF), which is a major, $1500 \mathrm{~km}$ long, dextral strike-slip continental transform fault across northern Turkey (Figure 2A). The lake is located on the northern hills of Kelkit Valley at an approximate orthogonal distance of $2.5 \mathrm{~km}$ from the NAF. Göllüköy Lake and its catchment cover an area of $0.11 \mathrm{~km}^{2}$ and $0.81 \mathrm{~km}^{2}$, respectively (Figure 2B). The lake's perimeter is invaded by reeds and its maximum water depth is $7.3 \mathrm{~m}$ (Figure $2 \mathrm{C})$.

The westward escape of the Anatolian microplate away from the Arabia-Eurasia collision at an approximate rate of $20-25 \mathrm{~mm} / \mathrm{yr}$ has resulted in strain release along the NAF during the $20^{\text {th }}$ century through successive major earthquakes (M > 7) that were associated with dextral slip of up to $7.5 \mathrm{~m}$ (Barka, 1992; Hubert-Ferrari et al., 2002; Şengör et al., 2005; Reilinger et al., 2006; Kozacı et al., 2007). Figure 2D illustrates the compilation of $20^{\text {th }}$ century and historical earthquakes along the NAF that affected the region around Göllüköy Lake (Barka 1996; Ambraseys and Jackson, 1998; Guidoboni and Comastri, 2005; Ambraseys, 2009). 


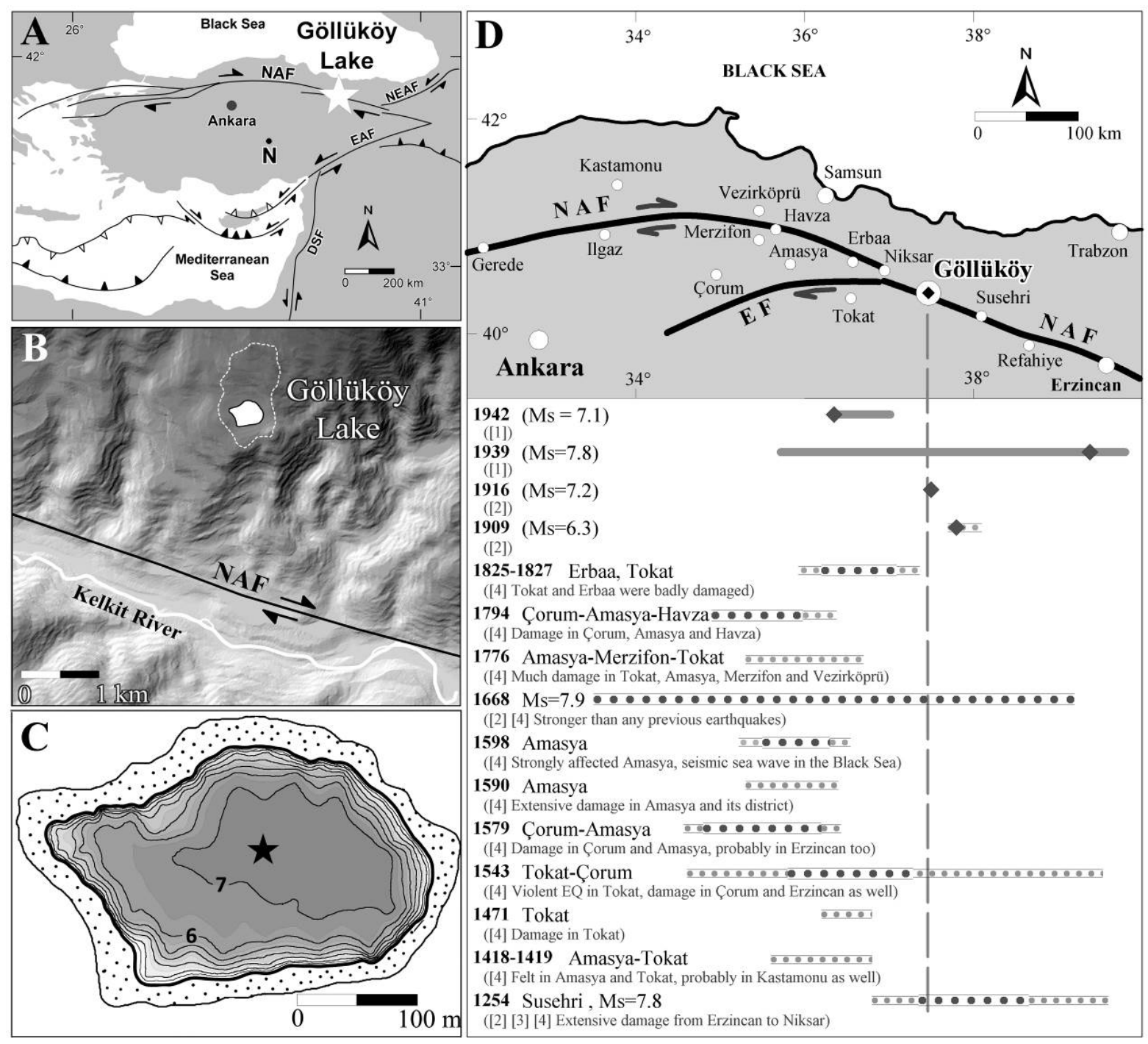

Figure 2. (A) General tectonic setting of Anatolia and its vicinity (simplified from Bozkurt, 2001; Şengör et al., 2005; Reilinger et al., 2006). NAF: North Anatolian Fault, NEAF: Northeast Anatolian Fault, EAF: East

Anatolian Fault, DSF: Dead Sea Fault. Göllüköy Lake is labelled by the white star, and Nar Lake by "N". (B) Shaded relief map of the area around Göllüköy Lake. White dashed line stands for the catchment boundary. (C) Bathymetric map of Göllüköy Lake. The dotted area stands for the extent of phragmites around the lake and the black star for coring location. (D) Upper panel: Geographic setting of the NAF with respect to the settlements mentioned in the historical seismicity records. Lower panel: Diamonds stands for the epicentral locations of the $20^{\text {th }}$ century earthquakes, solid lines for known surface ruptures and dotted lines for the approximate extend of damage along the NAF. The thicknesses of the lines are relative to the intensity of the damage ([1] Barka, 1996; [2] Ambraseys and Jackson, 1998; [3] Guidoboni and Comastri, 2005; [4] Ambraseys, 2009).

\section{Methods}

\subsection{Bathymetry and Coring}

The bathymetric map of Göllüköy Lake was produced by using a sonar equipped Garmin GPS Map 178 (Figure $2 \mathrm{C}$ ). Seismic sub-bottom profiling was attempted as well, but the signal penetration was very limited due to the high gas content of the sediments. In the light of the obtained bathymetric information, one gravity core (GK2007-G; 0.6-m-long, 6-cm-diameter) and one piston core (GK2007; 3.1-m-long, 10-cm-diameter), which were $3 \mathrm{~m}$ apart from each other, were retrieved at the deepest part of the lake in the summer of 2007 (star in Figure 2C). The gravity corer was used to sample the deposits at the sediment/water interface, which are poorly recovered or lost during piston coring. Visual inspection of the sediment/water interface through the transparent liner of the gravity core and established stratigraphic correlation between the gravity and piston cores assured the complete and undisturbed recovery of Göllüköy Lake sediments. 


\subsection{High-resolution Core Scanning}

Physical and geochemical properties of the sediment cores were measured using Geotek multi-sensor core logger (MSCL), ITRAX micro-XRF core scanner and SCOPIX X-ray image-processing system. The sediment cores were split into two halves at the research unit AGES (Argiles, Géochimie et Environnement Sédimentaires) of the University of Liège. One half was used for core scanning and the other for organic geochemistry and dating (short-lived radionuclides and AMS ${ }^{14} \mathrm{C}$ ). Magnetic susceptibility profiles were obtained at $5 \mathrm{~mm}$ resolution by Geotek Bartington point sensor on split core surfaces, at the Institute for Applied Geophysics and Geothermal Energy at RWTH Aachen University. The split cores were then sent to Stockholm University's core processing laboratory for ITRAX micro-XRF core scanning. In order to measure a wide range of elements and achieve high sampling resolution, the Mo-tube was set to $45 \mathrm{kV}-25 \mathrm{~mA}$ of voltage/current pair, and to XRF exposure time of $15 \mathrm{~s}$ for every $2 \mathrm{~mm}$ ( $40 \mathrm{~s}$ for the gravity core). In this way, ITRAX constructs XRF spectra for every $2 \mathrm{~mm}$. Semi-quantitative concentration profiles of different elements through the sediment cores are plotted based on the variation of their peak areas on XRF spectra. High-resolution radiographic and RGB images on the split cores were captured by ITRAX as well. Furthermore, centimetre-thick sediment slices, which were obtained by pushing aluminium $\mathrm{u}$-channels in the open half cores and extracting them using an eloctroosmotic knife, were scanned by the SCOPIX X-ray image-processing system at the EPOC laboratories of University of Bordeaux-I (Migeon et al., 1999). X-ray images obtained from these thin slices allowed a better investigation of 2D sedimentary structures.

\subsection{Organic Geochemistry}

The content and the source of organic matter in lacustrine sediments are generally investigated to understand sedimentary processes and paleoenvironmental conditions. Weight loss on ignition (LOI) at $550^{\circ} \mathrm{C}$ for 4 hours (Dean, 1974) was measured at every $2 \mathrm{~cm}$ through the piston core in order to have a preliminary idea about the organic matter content of the sediments. Moreover, after digesting the carbonate content by $\mathrm{HCl}$, stable carbon isotope $\left(\delta^{13} \mathrm{C}\right.$ ), total organic carbon (TOC) and total nitrogen (TN) measurements were carried out at every $5 \mathrm{~cm}$ by element analyser and mass spectrometer at the Oceanology Laboratory of the University of Liège.

Accordingly, the source of the organic matter in the sediments (i.e. lacustrine vs. terrestrial) is assessed based on TOC/TN ratios and $\delta^{13} \mathrm{C}$ values (Meyers and Teranes, 2001).

\subsection{Chronology}

The activities of ${ }^{137} \mathrm{Cs}$ and excess ${ }^{210} \mathrm{~Pb}\left({ }^{210} \mathrm{~Pb}\right.$ xs $)$ were measured on 15 samples $(1 \mathrm{~cm}$-thick) along the $0.6 \mathrm{~m}$-long gravity core (GK2007-G) by using a low-background, high efficiency well-type gamma spectrometer at the University of Bordeaux (Schmidt et al., 2014). The chronology of the GK2007-G core was established based on the peaks in ${ }^{137} \mathrm{Cs}$ profile and on the exponential decay of ${ }^{210} \mathrm{~Pb}_{\mathrm{xs}}$ activity. For the older periods, radiocarbon chronology was established on GK2007 piston core by AMS radiocarbon dates, which were carried out at the AMS facility at the University of Arizona. Radiocarbon dates were calibrated by using OxCal 4.2.3 software (Bronk Ramsey, 2013) based on the IntCal13 atmospheric curve of Reimer et al. (2013). In addition to 11 bulk sediment samples, different organic fractions in the sediments were dated, such as charcoals, Ephippia of Daphnia (chitinous shells enclosing the eggs) and phragmite remains (Figure 3). Furthermore, the radiocarbon chronology was refined by regional time-stratigraphic correlation of Göllüköy Lake record with the varve-based $\delta^{18} \mathrm{O}$ record of Nar Lake.
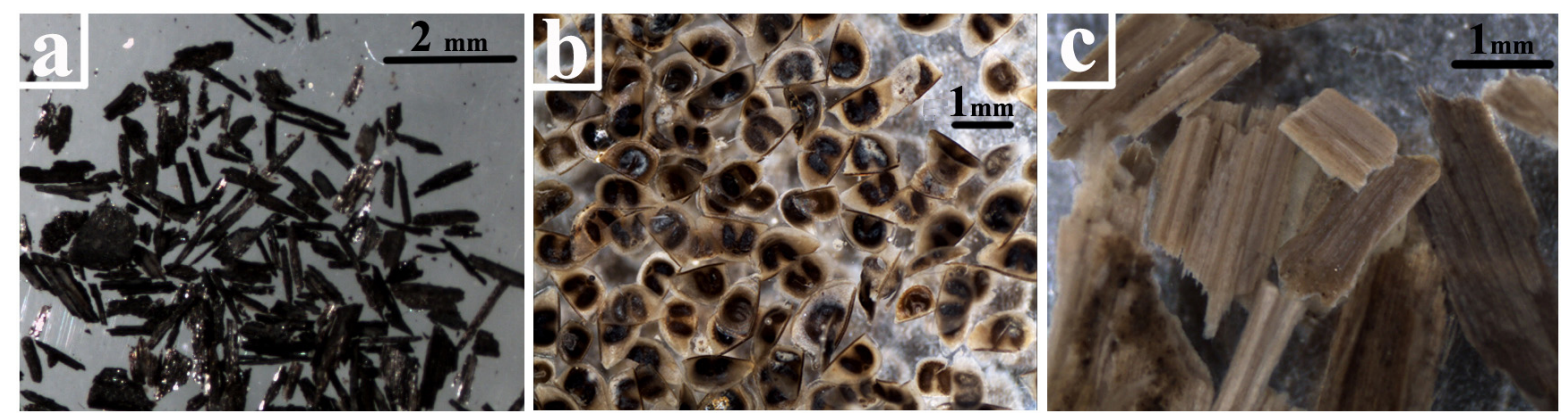

Figure 3. Organic fractions of sediments submitted for radiocarbon dating. (a) Charcoals, (b) Ephippia of Daphnia, and (c) Phragmite remains. 


\subsection{Principle Component Analysis}

The methods mentioned above yield a number of different variables measured on the sediment cores. Nevertheless, these variables are not completely independent from each other. For this kind of datasets, multivariate statistical methods are commonly applied to investigate inter-variable relations (Davis, 2002). In the present study, principle component analysis (PCA) was applied on the ITRAX dataset, which comprises the distributions of 24 elements through the cores. Basically, PCA reduces the number of variables by grouping correlated elements and producing new sets of variables, called principle components (PCs). For this purpose, each variable is first standardized (Eq. 4.5.1) in order to create comparable units, and then they are processed by SPSS software.

$z=\frac{x-\mu}{\sigma}$

where $\mathrm{x}$ : data value, $\mu$ : mean of the dataset, and $\sigma$ : standard deviation of the dataset.

\section{Results and Discussions}

\section{1. Identification of sedimentary events and chronology}

All measured parameters along the gravity and piston cores are presented in Figure 4. The correlation of magnetic susceptibility profiles between the piston and gravity cores (Figure 4A) confirms that the sediment loss at the top of the piston core is about only a few centimetres. Both cores are mainly composed of homogeneous grey-green carbonaceous mud as background sedimentation. Even though it is not clearly evidenced by the ITRAX micro-XRF profiles in Figure 4B and 4C, the proxies representing the organic matter content of the sediments in Figure 4A ( $\mathrm{LOI}_{550}$, TOC and TN profiles) reveal that there are six organic-rich intercalations in the sequence, namely E1-E6. These intercalations clearly stand out with respect to the background sediments as reddish-brown layers on the RGB images and as lighter grey colours on the radiographic images.

The sedimentation pattern is further examined using the ITRAX geochemical profiles. By visual inspection, it can be recognized that some profiles are correlated (e.g., Fe, Ti and K). Principle Component Analysis (PCA) was applied on this multivariate dataset to group the correlated elements and to produce new sets of variables (i.e. PCs). In fact, the total number of PCs is equal to the number of variables, but only few of them can be adequate to explain the total variance at a significant level. The first run of the PCA on the Göllüköy

geochemical dataset yields five PCs, whose eigenvalues are higher than 1.0, and which account for $62.7 \%$ of the total variance (Figure 5B). The results are further improved by evaluating the communalities (Figure 5A), which represent the contribution of each variable to the PCs. The contributions of $\mathrm{Ni}, \mathrm{V}$ and $\mathrm{Zr}$ are lower relative to the other elements (Figure 5A and 5C), and hence they are considered as outliers. The second run, without the outliers, results in five PCs explaining almost 70\% of the total variance (Figure 5D). The correlations of each element with the produced PCs are tabulated in Figure 5E. In addition, each PC and its corresponding elements are plotted in Figure 5F in order to visualize their relation. Accordingly, the PCA reveals two distinct elemental associations representing detrital aluminosilicates $\left(\mathrm{PC}_{1}: \mathrm{Fe}, \mathrm{Ti}, \mathrm{K}, \mathrm{Si}, \mathrm{Rb}, \mathrm{Co}, \mathrm{Mn}, \mathrm{Zn}\right)$ and carbonates $\left(\mathrm{PC}_{2}: \mathrm{Ca}\right.$, $\mathrm{Sr}, \mathrm{Sb}$ ). The reliability of the rest of the elemental profiles, which are represented by $\mathrm{PC}_{3}, \mathrm{PC}_{4}$ and $\mathrm{PC}_{5}$, is questionable because their raw counts are quite low. Most of them are close to the detection limits of ITRAX and may be even measurement noise.

It is well-known that elemental profiles obtained by ITRAX micro-XRF scanner are semi-quantitative proxies in nature. In addition to the geochemical properties of the sediments, raw ITRAX datasets bear traces of the physical properties of the sediments like water and organic matter content. In order to minimize these effects and to evaluate relative changes in elemental profiles, inter-element ratios are accepted as more reliable proxies for paleoenvironmental and paleoclimatic interpretations (e.g., Croudace et al., 2006; Kylander et al., 2011; Avşar, 2013). Figure 6 presents the inter-PC ratios along the Göllüköy piston core. The organic-rich intercalations (E1E6) can clearly be seen on the $\mathrm{PC}_{3} / \mathrm{PC}_{1}$ profile. This observation supports the results obtained by Löwemark et al. (2011), who noted that Al-normalized Ti and Fe profiles correlate with the organic matter content of sediments. It should be noted that $\mathrm{PC}_{3}$ represents $\mathrm{Mg}$ and $\mathrm{Al}$ (Figure 5E); however $\mathrm{Mg}$ and $\mathrm{Al}$ data measured by ITRAX with Mo tube is not reliable, because $\mathrm{Mg}$ is out of the detection range and $\mathrm{Al}$ data generally have very low signal-to-noise ratio. For this reason, $\mathrm{Mg}$ and $\mathrm{Al}$ profiles presented in this study should not be interpreted as the variations in the concentration of these elements in the sediments. Most probably, increase in the organic matter content of sediments amplifies the values of XRF spectrum around the energy levels of Mg and Al. 


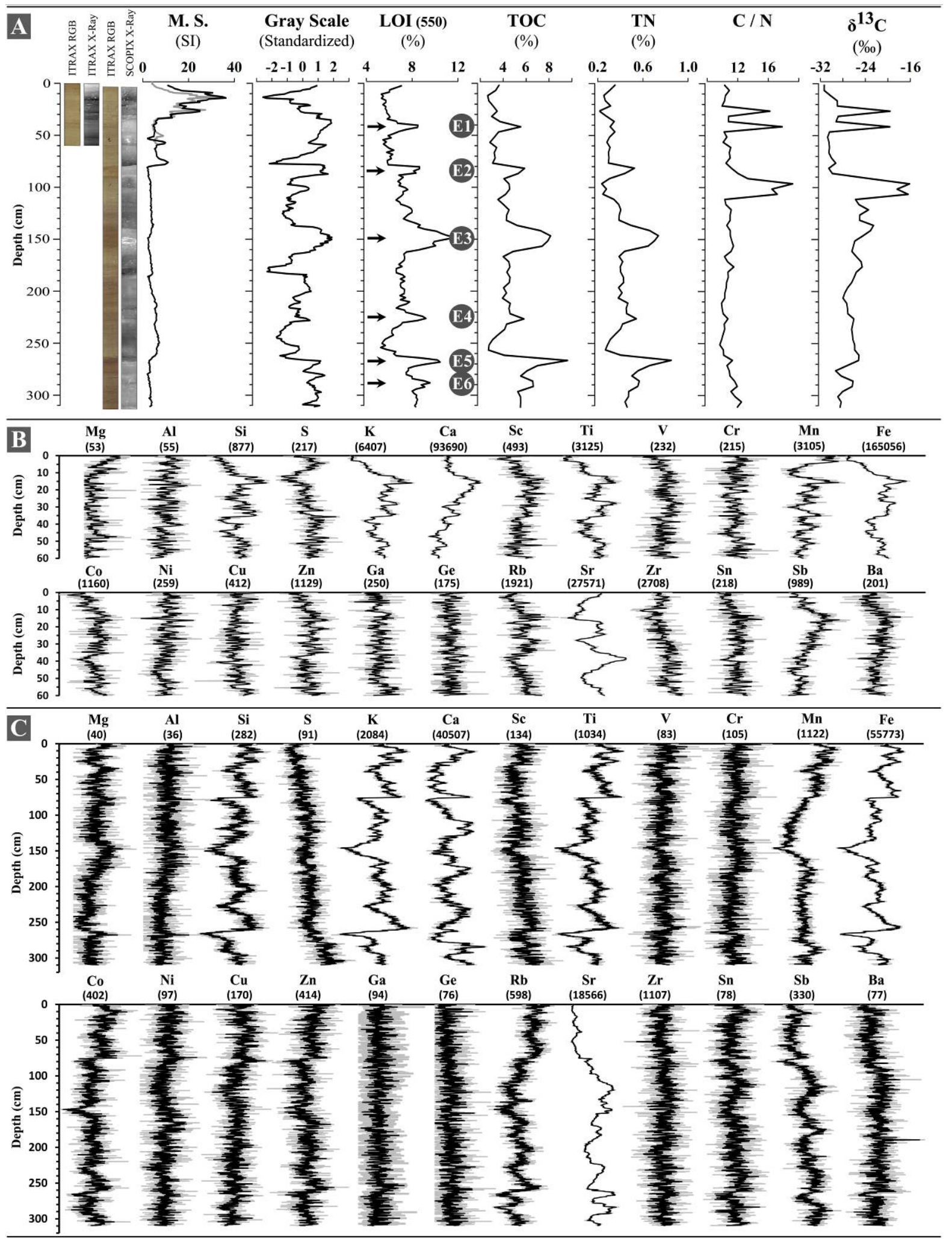

Figure 4. (A) Radiographic and RGB images captured by ITRAX and SCOPIX on the gravity and the piston cores. Magnetic susceptibility (M.S.), radiographic grey-scale, loss-on-ignition $\left(\mathrm{LOI}_{550}\right)$, total organic carbon (TOC), total nitrogen $(\mathrm{TN})$, carbon/nitrogen atomic ratio $(\mathrm{C} / \mathrm{N})$ and carbon stable isotope $\left(\delta^{13} \mathrm{C}\right)$ measurements, (B) Standardized elemental distributions obtained by ITRAX micro-XRF core scanner along the short gravity core, and (C) presents the ITRAX data along the piston core. Grey lines are the raw data where the black lines overlapping them are the 3-point moving averages. Note that the elemental profiles are standardized, but the mean raw counts for each profile are provided in parenthesis. 


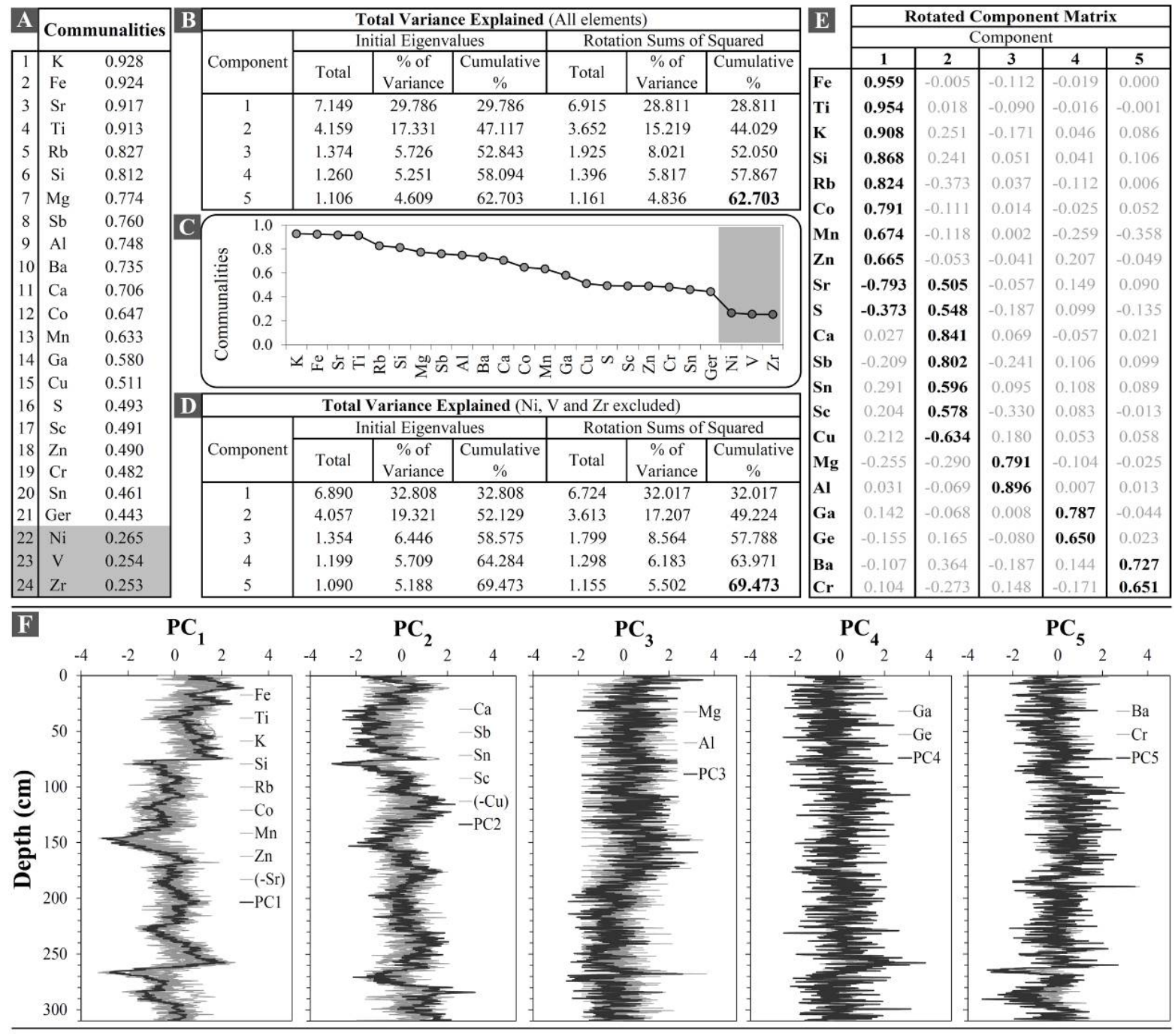

Figure 5. Steps and results of principal component analyses on ITRAX dataset. (A) Communalities of each element. The grey area represent low communality elements which are later excluded from the analysis, (B) The contribution of each principal component in total variance explained when all elemental data is used, (C) The plot of communalities, (D) The contribution of each principal component in total variance explained when low communality elements are excluded, (E) Correlation coefficients of each element with final principal components, $(\mathrm{F})$ The plot of principle components $\left(\mathrm{PC}_{1,2 . .}\right)$ and corresponding elements with respect to depth.

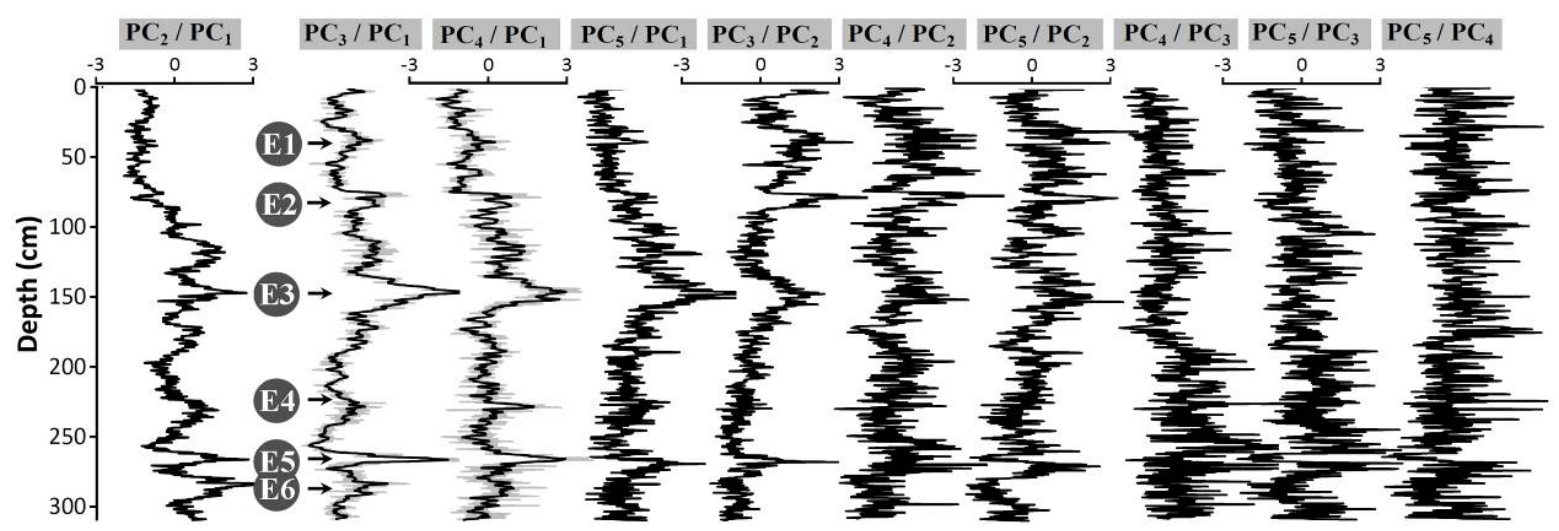

Figure 6. Inter-PC ratios along the GK2007 piston core. The sedimentary events (E1-E6) are obvious especially on the $\mathrm{PC}_{3} / \mathrm{PC}_{1}$ profile, which highly correlates with the organic matter content profiles presented in Figure $4 \mathrm{~A}$. 
All of the acquired data from the Göllüköy sedimentary sequence confirm the presence of organic-rich layers that are interbedded within the background sedimentation and clearly differ from it in composition. The formation of such organic-rich layers could be related to seismic activity affecting the region or to the climatic fluctuations; e.g., dramatical lake water level changes, heavy-rain events or biogenic production variations in and around the lake. Unlike the historical paleoclimatic records, historical seismicity records in the region are abundant and well-acknowledged (e.g., Ambraseys, 2009). Therefore, the possible seismic origin of these layers can be tested by establishing a precise event chronology and comparing it with the historical seismicity records.

Figure 7A presents the ${ }^{137} \mathrm{Cs}$ and ${ }^{210} \mathrm{~Pb}_{\mathrm{xs}}$ profiles along depth in the GK2007-G gravity core, and the corresponding sedimentation rates. The ${ }^{137} \mathrm{Cs}$ profile successfully reveals the two ${ }^{137} \mathrm{Cs}$ peaks corresponding to the maximum fallout of atmospheric nuclear weapon tests (1963) and the Chernobyl reactor accident (1986). In addition, the beginning of ${ }^{137} \mathrm{Cs}$ fallout, which corresponds to early $1950 \mathrm{~s}$, is observed around $38 \mathrm{~cm}$ depth. By assigning the top of the core to 2007, four reference points are obtained. Linear regression between these reference points $\left(\mathrm{r}^{2}=0.98\right)$ reveals a sedimentation rate (S.R.) of $0.64 \mathrm{~cm} / \mathrm{yr}$. On the other hand, the apparent maximum S.R. calculated from the exponential decay of ${ }^{210} \mathrm{~Pb}_{\mathrm{xs}}$ activity is $0.73 \mathrm{~cm} /$ year. Accordingly, an average S.R. of $0.68 \mathrm{~cm} / \mathrm{yr}$ seems reasonable for the top-most part of Göllüköy sequence. In Figure 7B and 7C, the PCs and the inter-PC ratios along the core are plotted with respect to time by considering a constant S.R. of $0.68 \mathrm{~cm} / \mathrm{yr}$. Even though $\mathrm{E} 1$ is not obvious in Figure 7B, the inter-PC ratio profiles (especially $\mathrm{PC}_{3} / \mathrm{PC}_{1}$ ) clearly reveal E1 (Figure 7C). According to the ${ }^{137} \mathrm{Cs}$ and ${ }^{210} \mathrm{~Pb}$ chronology, E1 is probably related to the $1939\left(\mathrm{M}_{\mathrm{s}}=7.7\right)$ Earthquake. It should be noted that the bottom two samples are from the deposits of E1 and they have significantly diluted ${ }^{210} \mathrm{~Pb}_{\mathrm{xs}}$ concentrations due to mixing with older displaced sediments. Therefore, $\mathrm{E} 1$ and the other similar anomalies down core can be accepted as instantaneous event deposits within the background sedimentation.

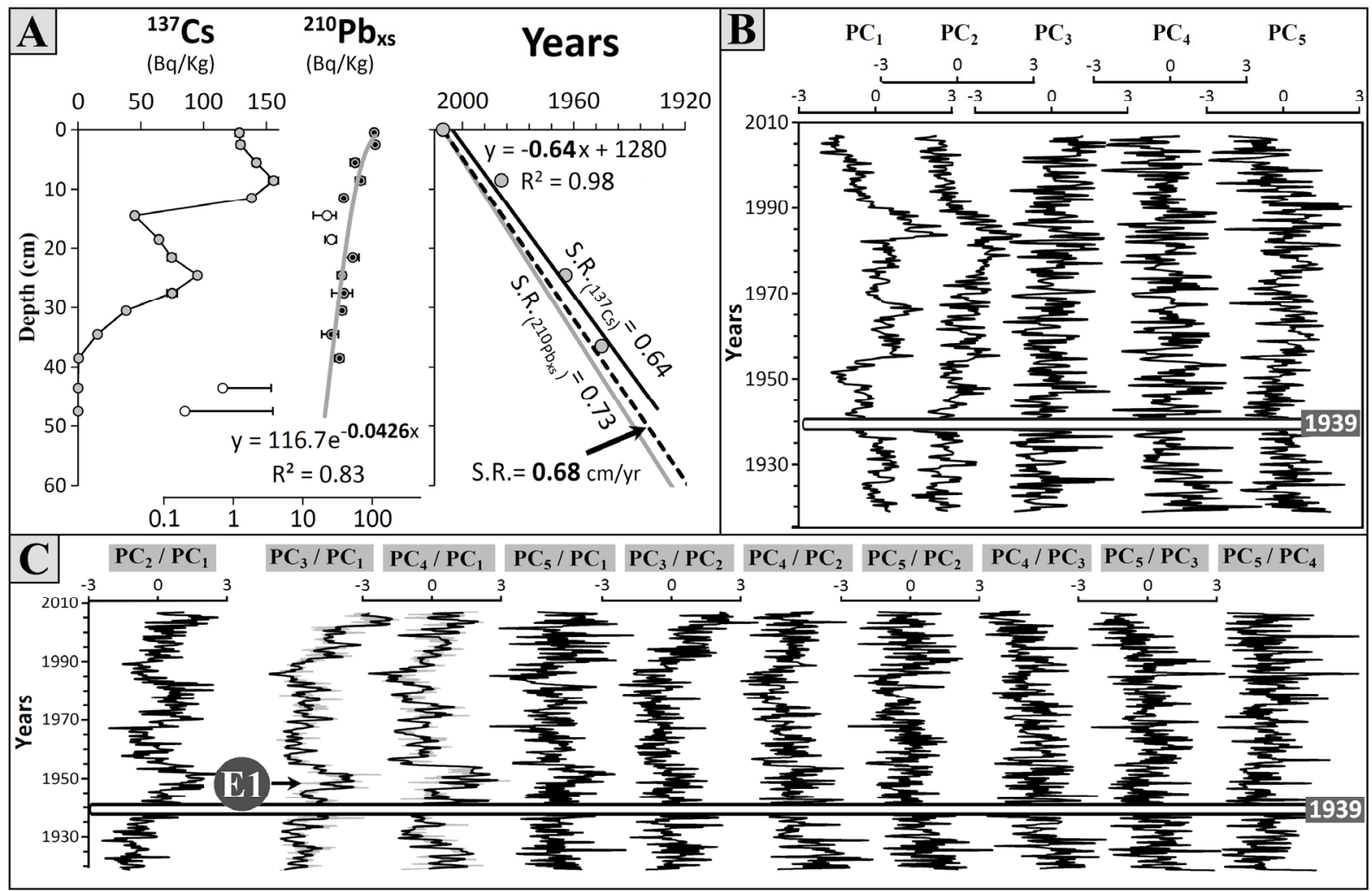

Figure 7. (A) ${ }^{137} \mathrm{Cs}$ and ${ }^{210} \mathrm{~Pb}_{\mathrm{xs}}$ profiles along the GK2007-G gravity core, and accordingly calculated sedimentation rates, (B) The plot of PCs along the GK2007-G core with respect to time (S.R. $=0.68 \mathrm{~cm} / \mathrm{yr}$ ), (C) Inter-PC ratio profiles along the core. The presented radionuclide chronology implies that E1 may be related to the $1939\left(\mathrm{M}_{\mathrm{s}}=7.7\right)$ Earthquake. The white circles in the ${ }^{210} \mathrm{~Pb}_{\mathrm{xs}}$ profile indicate the levels that were not included in the estimate, considering that these sediment layers are influenced by displaced sediments and do not correspond to regular sedimentation. 
On the piston core, radiocarbon dating on 11 bulk sediment samples reveals inverse ages possibly due to reworked organic matter and/or hard-water effect (Figure 8). Thus, different organic fractions of the sediments were dated; Phragmite remains, Ephippia of Daphnia and charcoals. The radiocarbon dates of these fractions provide significantly younger ages. The linear line passing through the youngest available radiocarbon dates reveals a constant sedimentation rate of $0.395 \mathrm{~cm} / \mathrm{yr}$. Accordingly, the dates of sedimentary events characterized by the anomalies in $\mathrm{LOI}_{550}$, TOC and $\mathrm{PC}_{3} / \mathrm{PC}_{1}$ profiles approximates the dates of some well-known historical earthquakes; E1 1939, E2 1825, E3 1668, E4 1418 and E6 1254 earthquakes (Figure 8). However, constant sedimentation rate along the core would not be realistic if we assume that the anomalies in the sequence are "events", which are expected to be instantaneously deposited. For this reason, the sediment chronology should be constructed by excluding the event layers from the sequence.

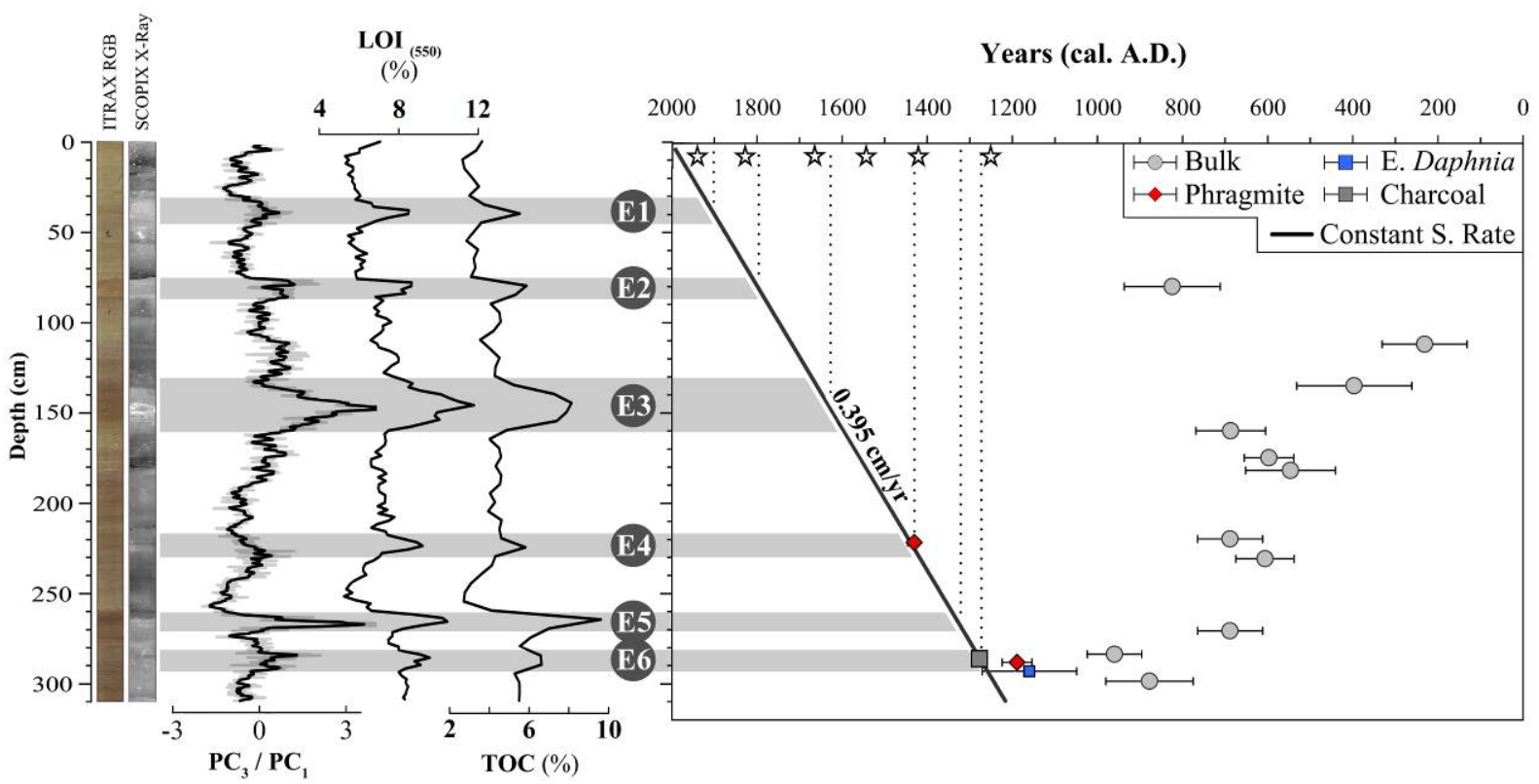

Figure 8. Sedimentary events (E1-E6) and the results of radiocarbon dating along the GK2007 piston core. Radiocarbon dating on the different organic fractions (i.e., Phragmite remains, Ephippia of Daphnia and charcoals) significantly improves the dating results. Accordingly, the dates of the sedimentary events roughly correlate with the well-known historical earthquakes (stars next to the upper axis of the plot). However, the sediment chronology requires further improvement by excluding the event deposits from the sequence. Furthermore, note that the radiocarbon dated organic fractions are extracted from event deposits, i.e. from E4 and E6. Hence, the real age of the sediments is anticipated to be younger.

In Figure 9A, the composite $\mathrm{LOI}_{550}$ profile is constructed by excluding the organic-rich event layers from the sequence. The resulting composite sequence is $218 \mathrm{~cm}$ long. Given that the sediments at the bottom of the sequence is ca. 800 years old (Figure 8 ), the average S.R. along the composite sequence is calculated as 0.28 $\mathrm{cm} / \mathrm{yr}$ (Figure 9A). However, the bottom of the sequence should be younger than 800 years; because the radiocarbon dated organic fractions were extracted from the event deposits and they are expected to be reworked. In order to determine the amount of reworking effect on our sediment chronology, we compare our proxy record with another precisely dated record from the region. Avşar et al. (2014) showed that regional time-stratigraphic correlations between proxy records can be a strong tool to cross-check or even to improve age-depth models in Anatolia. Figure 9B presents the overlapped plots of the Göllüköy composite $\mathrm{LOI}_{550}$ profile based on constant S.R. of $0.28 \mathrm{~cm} / \mathrm{yr}$ and the varve-based $\delta^{18} \mathrm{O}$ record of Nar Lake (Jones et al., 2006), which is located $\sim 350 \mathrm{~km}$ southwest of Göllüköy Lake. Obviously, the two records have similar trends. If the S.R. is assumed to be 0.33 $\mathrm{cm} / \mathrm{yr}$, which yields 140 years younger date at the bottom of the core, the similarity between the records becomes more obvious (Figure 9C). Furthermore, the Göllüköy record is fine-tuned to the Nar Lake record in Figure 9D. The age-depth model resulting from fine-tuning does not significantly deviate from the age-depth model having a constant S.R. of $0.33 \mathrm{~cm} / \mathrm{yr}$. Furthermore, the fine-tuned model seems more reasonable because it reveals a S.R. of $0.53 \mathrm{~cm} / \mathrm{yr}$ for the top-most $30 \mathrm{~cm}$ of the sequence, which is close to the one calculated by radionuclide dating (i.e., $0.68 \mathrm{~cm} / \mathrm{yr}$ ). In addition, the compaction effect is observed on the fine-tuned model, which reveals higher S.R. at the top of the sequence compared to the lower parts. This age-depth model also reveals even the sediment loss at the top of the core due to piston coring procedure. Not only the $\mathrm{LOI}_{550}$ profile but also the ratio 
of sulphur (S) to the detrital aluminosilicate elements (e.g., Si, K, Ti and Fe) correlates with the $\delta^{18} \mathrm{O}$ record of Nar Lake (Figure 9E). Avşar et al. (2014) demonstrated that this ratio can be used as a proxy to evaluate paleoclimatic conditions in Yeniçağa Lake, which is located $\sim 470 \mathrm{~km}$ to the west of Göllüköy Lake.

Accordingly, warmer and wetter climatic conditions favour high biogenic production in and around the lake, which results in organic S enrichments in the sedimentary sequence. Similarly, it is seen in Figure 9E that highprecipitation/low-evaporation climatic conditions are represented by higher $\mathrm{S} / \mathrm{Av}_{\mathrm{Si}, \mathrm{K}, \mathrm{Ti}, \mathrm{Fe}}$ values, pointing out higher organic matter content in the Göllüköy sediments.

In the light of the above-mentioned observations, the fine-tuned age-depth model established in this study seems reasonable and can be applied to the Göllüköy sedimentary sequence. However, this kind of time-stratigraphic correlations and tuning should be done with care. Although tuning can be applied to synchronize fossil proxy archives, one should be aware of the risks related to this process. Blaauw (2012) emphasizes that the amount of temporal shift induced by aligning the proxy archives should not exceed quantified chronological uncertainties from absolute age-depth models. In addition, tuned age-depth curves should be checked for unlikely sedimentation rates. As it is seen in Figure 9A, our fine-tuned age-depth model does not contain dramatic changes in the sedimentation rates along the core. The maximum deviation of the fine-tuned model from the radiocarbon based model (S.R. $=0.28 \mathrm{~cm} / \mathrm{yr}$ ) is ca. 140 years at the bottom of the core. It should be noted that this deviation is less than the error ranges of the most of the radiocarbon dates measured on the bulk sediment samples (Figure 8).

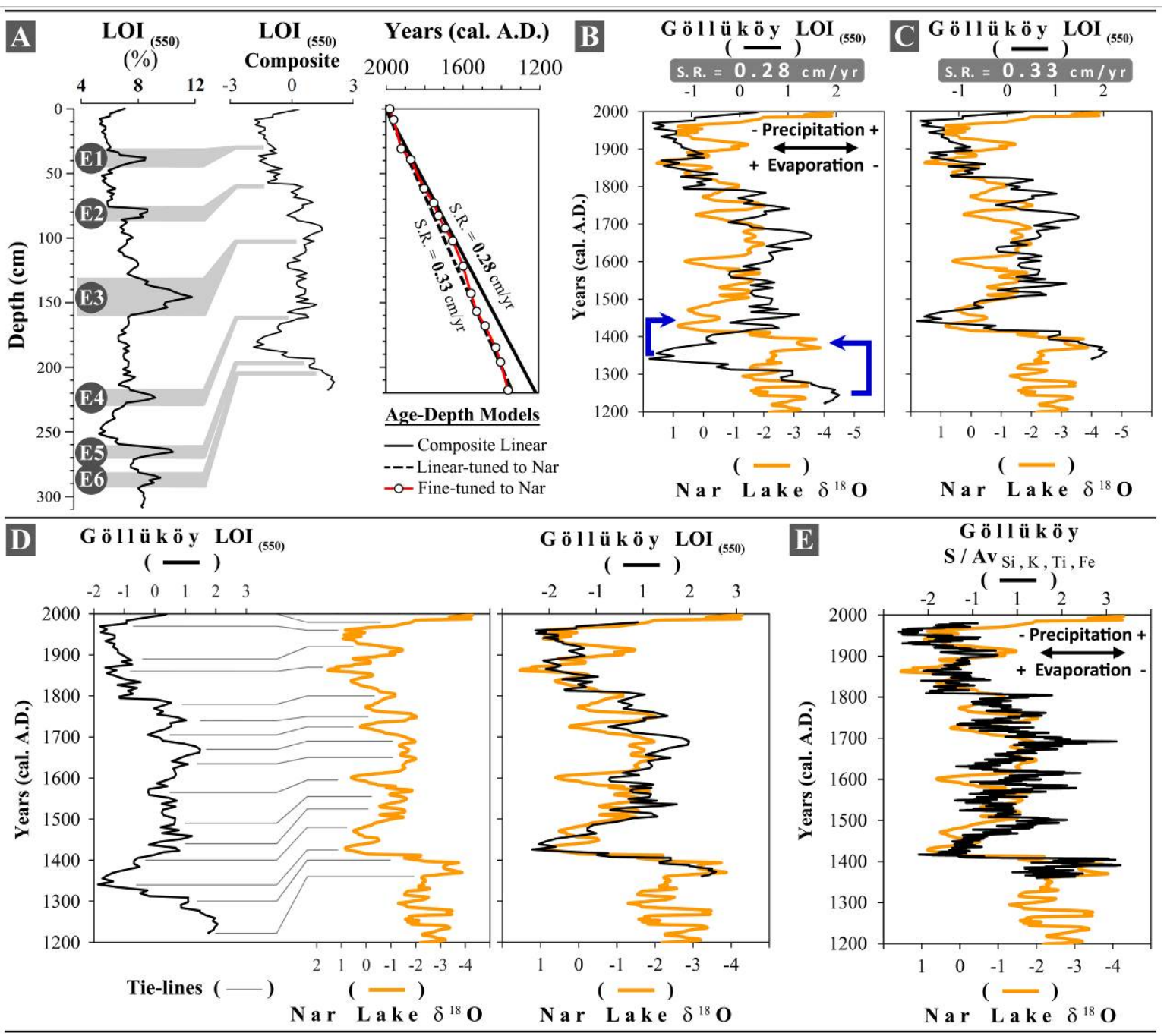

Figure 9. (A) Excluding the event layers from the Göllüköy sequence and the obtained composite sequence, as well as the constructed age-depth models, (B) Overlapped plots of the varve-based $\delta^{18} \mathrm{O}$ record of Nar Lake (Jones et al., 2006) and the Göllüköy composite loss-on-ignition $\left(\mathrm{LOI}_{550}\right)$ profile based on constant sedimentation rate (S.R.) of $0.28 \mathrm{~cm} / \mathrm{yr}$, (C) Overlapped plots of the two records if the S.R. along the Göllüköy sequence is assumed to be $0.33 \mathrm{~cm} / \mathrm{yr}$, (D) Fine-tuning of the Göllüköy record to the Nar Lake record and the 
resulting overlapped plots. Note that the dates of the tie-lines at the Nar Lake side correspond to the nodes of the fine-tuned age-depth model in (A), (E) Overlapped plots of the Göllüköy S/Av $v_{\mathrm{Si}, \mathrm{K}, \mathrm{Ti}, \mathrm{Fe}}$ ratio and the Nar Lake record. High-precipitation/low-evaporation climatic conditions are represented by higher $\mathrm{S} / \mathrm{Av}_{\mathrm{Si}, \mathrm{K}, \mathrm{Ti}, \mathrm{Fe}}$ values and higher organic matter contents in the Göllüköy sediments.

\subsection{Comparison of the event chronology with the historical seismicity records}

In Figure 10, the sedimentary event chronology in Göllüköy sequence is compared with the historical seismicity records in the region. The temporal correlation between the events and the historical earthquakes is not evident by the preliminary linear age-depth model (i.e., S.R. $=0.28 \mathrm{~cm} / \mathrm{yr}$ ), which is uniquely based on the radiocarbon dates. The correlation significantly improved when the fine-tuned age-depth model is used. The dates of the sedimentary events deviates only ca. 20 years from the historical earthquakes.

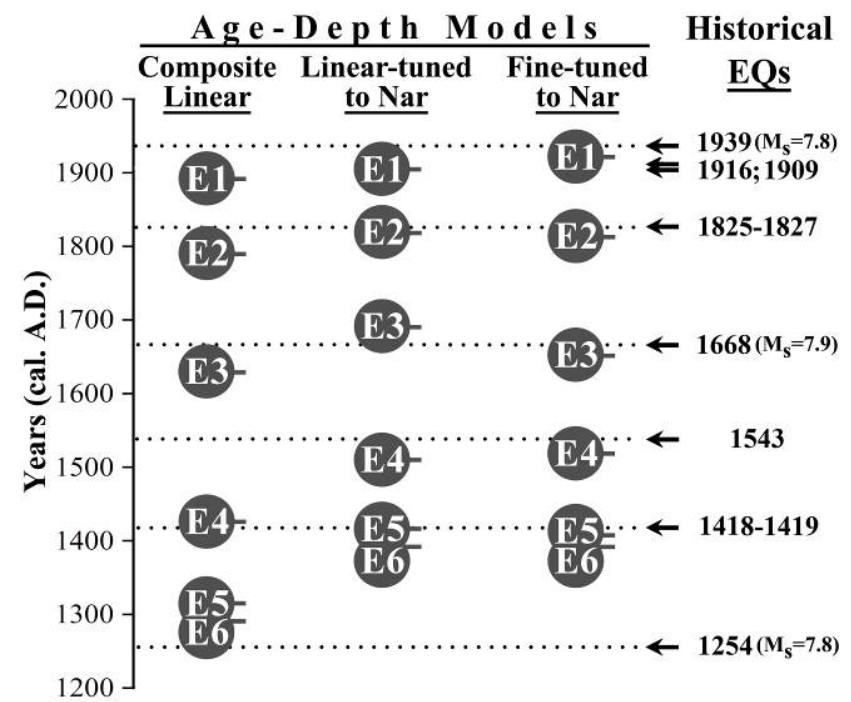

Figure 10. Comparison of the sedimentary event chronology of the Göllüköy record with the historical seismicity records. The event chronology based on the fine-tuned age-depth model reveals that the organic-rich intercalations in the Göllüköy sequence temporally correlate with the well-known large historical earthquakes in the region.

Based on the information from Figure 2D and Figure 10, we can critically assess to which extent the Göllüköy Lake did record earthquakes. The orthogonal distance between Göllüköy Lake and the epicentral locations of the $1916\left(M_{s}=7.2\right)$ and the $1909\left(M_{s}=6.3\right)$ earthquakes is around $50 \mathrm{~km}$ (Ambraseys and Jackson, 1998), hence these earthquakes are susceptible to be recorded in the sequence. For this reason, E1 may also contain the traces of the 1916 and 1909 earthquakes, along with the 1939 earthquake, which ruptured the NAF located a few kilometres to the south of Göllüköy Lake. E2 would correspond to the 1825 earthquake, which caused extensive damage in Tokat and Erbaa, both located approximately $80 \mathrm{~km}$ to the west of Göllüköy Lake (Ambraseys, 2009). The 1794 and 1776 earthquakes, affecting mostly Amasya and its western vicinity, ca. $150 \mathrm{~km}$ to the west of the lake, are not recorded in the Göllüköy sequence. Another historical earthquake, which ruptured the part of the NAF next to the lake, took place in 1668 . This $M=8$ earthquake was the most catastrophic one ever known in Anatolia (Ambraseys, 2009), and it left the most significant event deposits in the Göllüköy sequence, i.e. E3. The 1598, 1590 and 1579 earthquakes strongly affected Çorum and Amasya, which are 150-200 km to the west of the lake (Ambraseys, 2009). Similar to the 1794 and 1776 earthquakes, these earthquakes are not recorded in the Göllüköy sequence. The 1543 earthquake, which would correspond to E4, was strongly felt in Tokat, located 80 $\mathrm{km}$ to the west of the lake. Damage was reported in Çorum and Erzincan as well, which are $200 \mathrm{~km}$ to both east and west of the lake. The Aşağıtepecik Lake, which is located along the NAF $100 \mathrm{~km}$ southeast of Göllüköy, also recorded an earthquake-induced sedimentary event around 1500s (Hubert-Ferrari et al., 2012). Between 1418-1419, Ambraseys (2009) states that a large earthquake was felt in Amasya, Tokat and probably in Kastamonu as well. This large earthquake is recorded in Göllüköy sequence as E5. No significant earthquake was recorded in the historical resources corresponding to E6, which is also relatively less distinct compared to the other events in the sequence. These observations imply that the Göllüköy Lake did not record the earthquakes, which occurred at a distance of more than ca. $100 \mathrm{~km}$. 


\subsection{Triggering mechanism of the sedimentary events}

The triggering mechanism for the organic-rich intercalations is discussed in the light of Figure 1, which illustrates a stratigraphical columnar section summarizing possible earthquake sedimentary traces reported in the literature. In general, earthquake sedimentary traces can be linked to co-seismic or post-seismic processes.

In Figure 1, co-seismic effects of earthquakes on lacustrine sedimentation are illustrated as in-situ soft sediment deformations and mobilized masses due to mass wasting events. Since Göllüköy sedimentary sequence does not show any primary sedimentary structures, it is impossible to observe soft sediment deformations even if the seismic shocks caused any. Mobilized masses of mass-wasting events are either unlikely due to the fact that the lake fills a flat basin.

A long-term post-seismic mechanism does not fit the Göllüköy Lake case. Sudden lake level changes due to tectonic activity are not expected since its basin is not tectonically controlled. Similarly, changes in water chemistry due to fluid emissions from the fault are unlikely. Seismically-induced landslides in catchments would increase sediment influx to the lake (see Section 2). If these landslides take place on densely vegetated slopes, terrestrial organic matter enrichments can be observed along the lake sedimentary sequence. However, organicrich layers in the Göllüköy sequence are of mainly aquatic origin. Observations under binocular showed that the content of these layers are mainly macro remains of aquatic plants, especially phragmites. In Figure 4A, this is supported by $\mathrm{C} / \mathrm{N}$ ratios and $\delta^{13} \mathrm{C}$ values. $\mathrm{C} / \mathrm{N}$ ratios and $\delta^{13} \mathrm{C}$ values imply that those macro plant remains are of aquatic origin rather than terrestrial. If they were terrestrial plant remains, both profiles would show significant peaks. Only the most recent organic matter enrichment is accompanied by terrestrial input, which may be attributed to a short term deforestation. In addition the catchment of Göllüköy Lake does not have steep slopes prone to landslides. It is thus unlikely that the observed organic matter enrichments are due to long-term postseismic mechanisms illustrated in Figure 1.

Among the post-seismic effects immediately after the seismic shock, homogenites and seismoturbidites are ruled out since mass-wasting is unlikely in Göllüköy Lake. Organic-rich intercalations along the Göllüköy sequence might be the result of sediment resuspension, which organic and clastic fractions are expected to be separated due to gravitational segregation during the subsequent deposition. This segregation would result in organiclack/clastic-rich layers overlain by organic-rich deposits. However, this kind of sedimentary pattern confirming gravitational segregation is observed on neither the profiles related to the organic matter content nor the radiographic images.

In the available lacustrine paleoseismology literature, there is no mechanism that explains how macroscopic aquatic plant remains could be deposited at the middle parts of Göllüköy Lake. A security camera record during the 2010 Baja California earthquake $\left(\mathrm{M}_{\mathrm{w}}=7.2\right)$ provides some clues for this question (A_video1). The video illustrates the earthquake-triggered water oscillation in the swimming pool of a hotel in Mexicali, which is located $40 \mathrm{~km}$ to the NNW of the earthquake epicentre. Accordingly, we infer that water oscillation during earthquakes (seiche effect) can be severe enough to erode, detach and resuspend decomposed macro aquatic plant remains (i.e., phragmites) from the littoral zone of the lake. Subsequently, the suspended organic material is transported towards the inner parts of the lake and deposited as intercalations within the background sedimentation. The next step is to assess how Göllüköy Lake differs from the other lakes investigated in the available lacustrine paleoseismology literature. It is known that small and narrow basins are more susceptible to generate seismically-induced water oscillations, as horizontal motions of the sides of basin are effective wave generators (e.g., McGarr, 1965; Barberopoulou et al., 2006). Avşar (2013) compares the basin geometries of 51 lakes worldwide, which have been investigated in the literature, in order to evaluate their susceptibility to seismically-induced water oscillation (seiche).

As a measure of basin narrowness, the ratios of maximum lake depth to lake area of 51 lakes are presented in Figure 11A. In order to better visualize the meaning of these ratios, isometric comparison of the basin geometries of four lakes are presented as well. It is seen that, except the lakes located in low-moderate seismicity regions, Göllüköy Lake is almost at the top of the list and hence relatively more susceptible to seiche. However, not only intense seiche waves but also decomposed organic material at the littoral zone of the lake is required in order to observe sedimentary traces like in Göllüköy Lake. In addition, the lake should be relatively small so that the organic material detached from the littoral zone can be transported enough to leave widespread sedimentary traces. Figure 11B presents the lake perimeter length to lake area ratios as a measure of organic matter abundance at the lake shores compared to its size. Göllüköy Lake is again close to the top of the list among the other lakes in the high-seismicity regions. For this sorting, the perimeters of all lakes are assumed to be completely invaded by aquatic plants. However, it is not the case in reality. In order to make more realistic sorting, Avşar (2013) uses Google Earth images to approximately determine the extent of aquatic plant invasion at the littoral zones of each lake. The sorting based on the aquatic-plant-invaded lake perimeter to the lake area ratios is presented in Figure 11C. Accordingly, Göllüköy Lake is at the top of the list. This implies that, in case 
of seismically-induced water oscillations, enough organic material is probably available at the shores of the lake to be detached, and the lake is relatively small so that detached material can be spread basin-wide.
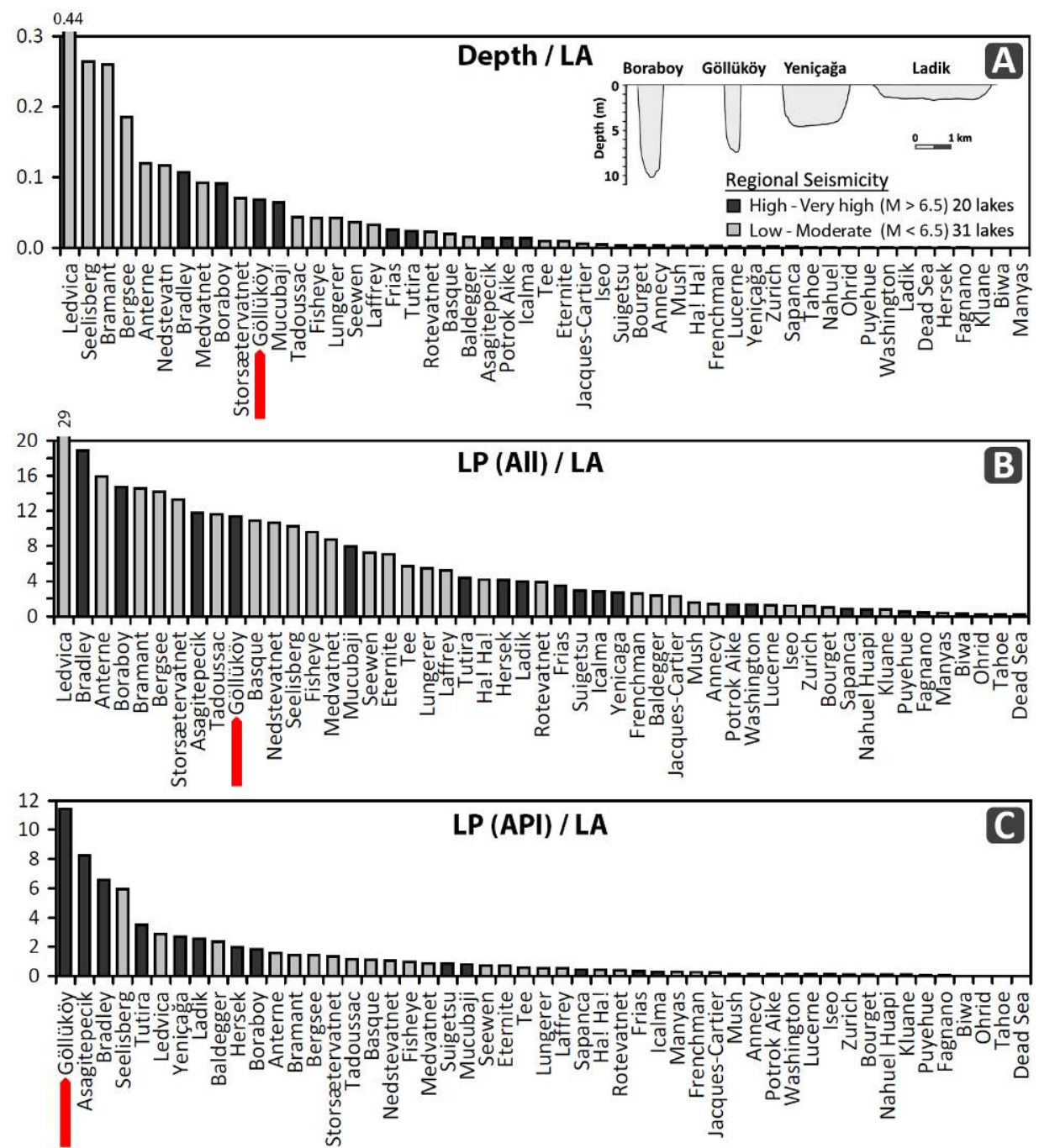

Figure 11. Comparison of the geometrical properties of 51 lakes in the available lacustrine paleoseismology literature in order to evaluate their susceptibility to seiche and its effects on lake shores. A) The maximum depth to lake area [LA] ratios and the isometric comparison of the basin geometries of four lakes, B) The total lake perimeter [LP(All)] to lake area [LA] ratios, and C) The aquatic-plant-invaded lake perimeter [LP(API)] to lake area [LA] ratios. (Modified from Avşar, 2013)

\section{Conclusions}

1. The Göllüköy sedimentary sequence illustrates a new type of seismites, i.e. organic-rich intercalations within the background sedimentation. The triggering mechanism is attributed to the detachment of aquatic plant remains at the lake shores by seismically-induced water oscillations, and their subsequent deposition in the middle parts of the lake. The rationale for the scarcity of these seismites in the lacustrine paleoseismological literature is investigated by comparing some physical and geometrical properties of Göllüköy Lake with 50 other lakes. The comparison suggests that its small size and narrow basin geometry make Göllüköy Lake susceptible to severe water oscillations during earthquakes. In addition, its aquatic-plant-invaded shores can provide enough decomposed organic material that can be detached when seismically-induced water oscillation takes place.

2. Dating on micro-charcoals, Ephippia of Daphnia and phragmite remains significantly improves the radiocarbon chronologies. 
3. Regional time-stratigraphic correlations and tuning of different proxy records can also highly improve sediment chronologies. In this study, the Göllüköy sedimentary record has been successfully tuned to the varve-based $\delta^{18} \mathrm{O}$ record of Nar Lake. Given that these two lakes are approximately $350 \mathrm{~km}$ apart from each other, the correlation between their proxy records implies that Nar Lake record can be a valuable "anchor" sedimentary archive for regional time-stratigraphic correlation applications in Anatolia.

\section{Acknowledgements}

This research was funded by the European Commission Marie Curie Excellence Grant Project "Understanding the irregularity of seismic cycles: A case study in Turkey" (MEXT-CT-2005-025617: Seismic Cycles), hosted by the Seismology Section of the Royal Observatory of Belgium. The coring was carried out by collaboration with Istanbul Technical University - Eastern Mediterranean Centre for Oceanography and Limnology (ITU-EMCOL). We are grateful to X. Boes, E. Damc1, D. Acar and C. Somuncuoğlu for their assistance and efforts during coring mission. L. Löwemark is appreciated for his training on ITRAX micro-XRF core scanner at the Stockholm University's core processing laboratory. We also thank to N. Tüfekçi for her constructive contributions to improve the manuscript. The authors would like to thank to G. Bezirci, E. E. Levi and A. İ. Çakıroğlu of Biology Department of Middle East Technical University (METU) for the description of Ephippia of Daphnia.

\section{$\underline{\text { References }}$}

Ambraseys, N.N., Finkel, C., 1995. The Seismicity of Turkey and Adjacent Areas: A Historical Review, 15001800. Muhittin Salih Eren, Istanbul, pp. 0-240.

Ambraseys, N., Jackson, J., 1998. Faulting associated with historical and recent earthquakes in the eastern Mediterranean region. Geophysical Journal International 133 (2), 390-406.

Ambraseys, N., 2009. Earthquakes in the Mediterranean and Middle East - A multidisciplinary study of seismicity up to 1900. Cambridge University Press, 968 pp.

Atwater, B., 1987. Evidence for great Holocene earthquakes along the outer coast of Washington State. Science 236, 942-944.

Atwater, B., Yamaguchi, D., Bondevik, S., Barnhardt, W., Amidon, L., Benson, B., Skjerdal, G., Shulene, J., Nanayama, F., 2001. Rapid resetting of an estuarine recorder of the 1964 Alaska Earthquake, Geol. Soc. Am. Bull. 113, 1193-1204.

Avşar, U., 2013. Lacustrine paleoseismic records from the North Anatolian Fault, Turkey. PhD thesis, Ghent University, Gent, Belgium.

Avşar, U., 2014. Potential use of river suspended-sediment observations to evaluate the effects of seismic shaking on sediment yield. Geophysical Research Abstracts 16, EGU2014-10834-1.

Avşar, U., Hubert-Ferrari, A., De Batist, M., Fagel, N., 2014. A 3400 year lacustrine paleoseismic record from the North Anatolian Fault, Turkey: Implications for bimodal recurrence behaviour. Geophysical Research Letters 41 (2), 377-384.

Barberopoulou, A., Qamar, A., Pratt, T.L., Steele, W. P., 2006. Long-period effects of the Denali Earthquake on water bodies in the Puget lowland: Observations and modeling. Bull. Seism. Soc. Amer. 96 (2), 519-535.

Barka, A.A., 1992. The North Anatolian fault zone. Annales Tectonicae 6, 164-195.

Barka, A.A., 1996. Slip distribution along the North Anatolian Fault associated with large earthquakes of the period 1939 to 1967. Bulletin of the Seismological Society of America 86, 1238-1254.

Beck, C., 2009. Late Quaternary lacustrine paleoseismic archives in north-western Alps: Examples of earthquake-origin assessment of sedimentary disturbances. Earth-Science Reviews 96, 327-344.

Becker, A., Ferry, M., Schnellmann, M., Giardini, D., 2005. Multiarchive palaeoseismic record of late Pleistocene strong earthquakes in Switzerland. Tectonophysics 400, 153-157.

Ben-Menahem, A., 1976. Dating historical earthquakes by mud profiles of lake-bottom sediments. Nature 262, 200-202.

Bertrand, S., Charlet, F., Chapron, E., Fagel, N., De Batist, M., 2008. Reconstruction of the Holocene seismotectonic activity of the Southern Andes from seismites recorded in Lago Icalma, Chile, $39^{\circ} \mathrm{S}$. Palaeogeogr. Palaeoclimatol. Palaeoecol. 259, 301-322. 
Bertrand, S., Doner, L., Akçer Ön, S., Sancar, U., Schudack, U., Mischke, S., Çagatay, M.N., Leroy, S.A.G., 2011. Sedimentary record of coseismic subsidence in Hersek coastal lagoon (Izmit Bay, Turkey) and the late Holocene activity of the North Anatolian Fault. Geochemistry Geophysics Geosystems 12, Q06002, doi:10.1029/2011GC003511.

Blaauw, M., 2012. Out of tune: the dangers of aligning proxy archives. Quaternary Science Reviews 36, 38-49.

Boes, X., Moran, S.B., King, J., Cagatay, M.N., Hubert-Ferrari, A., 2010. Records of large earthquakes in lake sediments along the North Anatolian Fault, Turkey. Journal of Paleolimnology 43, 901-920.

Bozkurt, E., 2001. Neotectonics of Turkey-A synthesis. Geodinamica Acta 14, 3-30.

Bronk Ramsey, C., 2013. OxCal Program v. 4.2.3 Radiocarbon Accelerator unit, University of Oxford, Oxford, U.K. (Available at https://c14.arch.ox.ac.uk/oxcal.html)

Caputo, R., Helly, B., 2008. The use of distinct disciplines to investigate past earthquakes. Tectonophysics 453 , 7-19.

Chapron, E., Beck, C., Pourchet, M., Deconinck, J.F., 1999. 1822 AD earthquake-triggered homogenite in Lake Le Bourget (NW Alps). Terra Nova 11, 86-92.

Chapron, E., Van Rensbergen, P, De Batist, M., Beck, C., Henriet, J.-P., 2004. Fluid-escape features as a precursor of large sub-lacustrine sediment slide in Lake Le Bourget, NWAlps, France. Terra Nova 16 (5), $305-311$.

Chevalier, M.-L., Ryerson, F.J., Tapponnier, P., Finkel, R.C., van der Woerd, J., Li Haibing, Liu Qing, 2005. Slip-rate measurements on the Karakorum Fault may imply secular variations in fault motion. Science 307, 411-414.

Chuang, S-C., Chen, H., Lin, G.W., Lin, C.W., Chang, C.P., 2009. Increase in basin sediment yield from landslides in storms following major seismic disturbance. Engineering Geology 103, 59-65.

Croudace, I.W., Rindby, A., Rothwell, R.G., 2006. ITRAX: description and evaluation of a new multi-function X-ray core scanner. In: Rothwell, R.G. (Ed.), New techniques in sediment core analysis. Geological Society London Special Publication, London, vol. 267, pp. 51-63.

Dadson, S.J., Hovius, N., Chen, H., Dade, W.B., Lin, J.C., Hsu, M.L., Lin, C.W., Horng, M.J., Chen, T.C., Milliman, J., Stark, C.P., 2004. Earthquaketriggered increase in sediment delivery from an active mountain belt. Geology 32 (8), 733-736.

Davis, J.C., 2002. Statistics and data analysis in geology. John Wiley \& Sons, New York, 638 pp.

Dean, W. E., Jr., 1974. Determination of carbonate and organic matter in calcareous sediments and sedimentary rocks by loss on ignition: Comparison with other methods. J. Sediment. Petrol. 44, 242-248.

Doig, R., 1986. A method for determining the frequency of large-magnitude earthquakes using lake sediments. Canadian Journal of Earth Sciences 23, 930-937.

Doig, R., 1990. 2300 yr history of seismicity from silting events in Lake Tadoussac, Charlevoix, Quebec. Geology 18, 820-823.

Doig, R., 1991. Effects of strong seismic shaking in lake sediments, and earthquake recurrence interval, Te'miscaming, Quebec. Canadian Journal of Earth Sciences 28, 1349-1352.

Doig, R., 1998a. Paleoseismological evidence from lake sediments for recent movement on the Denali and other faults, Yukon Territory, Canada. Tectonophysics 296, 363-370.

Doig, R., 1998b. 3000-Year Paleoseismological Record from the Region of the 1988 Saguenay, Quebec, Earthquake. Bulletin of the Seismological Society of America 88 (5), 1198-1203.

Fanetti, D., Anselmetti, F.S., Chapron, E., Sturm, M., Vezzoli, L., 2008. Megaturbidite deposits in the Holocene basin fill of Lake Como (southern Alps, Italy). Palaeogeography, Palaeoclimatology, Palaeoecology 259, 323340 .

Fraser, J., Vanneste, K., Hubert-Ferrari, A., 2010. Recent behavior of the North Anatolian Fault: Insights from an integrated paleoseismological data set. Journal of Geophysical Research 115, B09316, doi:10.1029/2009JB006982.

Guidoboni, E., Comastri, A., 2005. Catalogue of earthquakes and tsunamis in the Mediterranean area from the 11 th to the 15 th century. Istituto Nazionale di Geofisica e Vulcanologia, Bologna/Italy, pp.1037. 
Guyard, A., St-Onge, G., Chapron, E., Anselmetti, F.S., Francus, P., 2007. The AD1881 earthquake triggered slump and late holocene flood-induced Turbidites from Proglacial Lake Bramant,Western French Alps. In: Lykousis, V., Sakellariou, D., Locat, J. (Eds), Submarine Mass Movements and their Consequences. Springer, Berlin, pp. 279-286.

Hayward, B., Grenfell, H., Sabaa, A., Carter, R., Cochran, U., Lipps, J., Shane, P., Morley, M., 2006. Micropaleontological evidence of large earthquakes in the past 7200 years in southern Hawke's Bay, New Zealand. Quaternary Science Reviews 25, 1186-1207.

Hibsch, C., Alvarado, A., Yepes, H., Perez, V.H., Sebrier, M., 1997. Holocene liquefaction and soft-sediment deformation in Quito (Ecuador): a paleoseismic history recorded in lacustrine sediments. Journal of Geodynamics 24, 259-280.

Howarth, J.D., Fitzsimons, S.J., Norris, R.J., Jacobsen, G.E., 2012. Lake sediments record cycles of sediment flux driven by large earthquakes on the Alpine fault, New Zealand. Geology 40(12), 1091-1094.

Hubert-Ferrari, A., Armijo, R., Meyer, B., King, G.C.P., Barka, A., 2002. Morphology, displacement and slip rates along the North Antolian Fault (Turkey). Journal of Geophysical Research 107 (B10), 2235, doi:10.1029/2001JB000393.

Hubert-Ferrari, A., Avsar, U., El Ouahbi, M., Le Point, G., Fagel, N., 2012. Paleoseismic record obtained by coring a lacustrine sag-pond along the North Anatolian Fault (Turkey). Annals of Geophysics 55(5), 929-953.

Jones, M.D., Roberts, N.C., Leng, M.J., Türkes, M., 2006. A high-resolution late Holocene lake isotope record from Turkey and links to North Atlantic and monsoon climate. Geology 34, 361-364.

Kagan, E., Stein, M., Agnon, A., Neumann, F., 2011. Intrabasin paleoearthquake and quiescence correlation of the late Holocene Dead Sea. J. of Geophysical Research 116, B04311, doi:10.1029/2010JB007452.

Karlin, R.E., Holmes. M., Abella, S.E.B., Sylwester, R., 2004. Holocene landslides and a 3500-year record of Pacific Northwest earthquakes from sediments in Lake Washington. GSA Bulletin 116, 94-108.

Keefer, D.K., 1984. Landslides caused by earthquakes. Geological Society of America Bulletin 95, 406-421.

Keefer, D.K., 1999. Earthquake-induced landslides and their effects on alluvial fans. Journal of Sedimentary Research 69 (1), 84-104.

King, G.C.P., Bowman, D.D., 2003. The evolution of regional seismicity between large earthquakes. Journal of Geophysical Research 108, B22096, doi:10.1029/2001JB000783.

Kozacı, Ö., Dolan, J.F., Finkel, C.F., Hartleb, R., 2007. Late Holocene slip rate for the North Anatolian Fault, Turkey, from cosmogenic $36 \mathrm{Cl}$ geochronology: Implications for the constancy of fault loading and strain release rates. Geology 35(10), 867-870.

Kylander, M.E., Ampel, L., Wohlfarth, B., Veres D., 2011. High-resolution X-ray fluorescence core scanning analysis of Les Echets (France) sedimentary sequence: new insights from chemical proxies. J. of Quaternary Science 26, 109-117, doi:10.1002/jqs.1438.

Leroy, S.A.G., Boyraz, S., Gürbüz, A., 2009. High-resolution palynological analysis in Lake Sapanca as a tool to detect recent earthquakes on the North Anatolian Fault. Quaternary Science Reviews 28, 2616-2632.

Leroy, S.A.G., Schwab, M.J., Costa, P.J.M., 2010. Seismic influence on the last 1500-year infill history of Lake Sapanca (North Anatolian Fault, NW Turkey). Tectonophysics 486, 15-27.

Lignier, V., Beck, C., Chapron, E., 1998. Caractérisation géométrique et texturale de perturbations synsédimentaires attribuées à des séismes, dans une formation quaternaire glaciolacustre des Alpes (les Argiles du Trièves). C.R. Acad. Sci. Paris, Earth and Planetary Sciences 327, 645-652.

Lin, G.W., Chen, H., Chen, Y.H., Horng, M-J., 2008. Influence of typhoons and earthquakes on rainfall-induced landslides and suspended sediments discharge. Engineering Geology 97, 32-41.

Löwemark, L., Chen, H.-F., Yang, T.-N., Kylander, M., Yu, E.-F., Hsu, Y.-W., Lee, T.-Q., Song, S.-R., Jarvis S., 2011. Normalizing XRF-scanner data: A cautionary note on the interpretation of high-resolution records from organic-rich lakes. Journal of Asian Earth Sciences 40, 1250-1256.

McCalpin, J., 2009. Paleoseismology. Academic Press - Nature - pp. 613.

McGarr, A., 1965. Excitation of seiches in channels by seismic waves. Journal of Geophysical Research 70 (4), 847-854. 
Meyers, P.A., Teranes J.L., 2001. Sediment organic matter. In: Last, W.M., Smol, J.P. (Eds), Tracking Environmental Change Using Lake Sediments. Volume 2: Physical and Geochemical Methods. Kluwer Academic Publishers, Dordrecht, the Netherlands, pp. 239-269.

Migeon, S., Weber, O., Faugeres, J., Saint-Paul, J., 1999. SCOPIX: a new X-ray imaging system for core analysis. Geo-Marine Letters 18, 251-255.

Migowski, C., Agnon, A., Bookman, R., Negendank, J.F.W., Stein, M., 2004. Recurrence pattern of Holocene earthquakes along the Dead Sea transform revealed by varve-counting and radiocarbon dating of lacustrine sediments. Earth and Planetary Science Letters 222, 301- 314.

Mirecki, J.E., 1996. Recognition of the 1811-1812 New Madrid earthquakes in Reelfoot Lake, Tennessee sediments using pollen data. Journal of Paleolimnology 15, 183-191.

Moernaut, J., De Batist, M., Charlet, F., Heirman, K., Chapron, E., Pino, M., Brümmer, R., Urrutia, R., 2007. Giant earthquakes in South-Central Chile revealed by Holocene mass-wasting events in Lake Puyehue. Sedimentary Geology 195, 239-256.

Moernaut, J., De Batist, M., Heirman, K., Van Daele, M., Pino, M., Brümmer, R., Urrutia, R., 2009. Fluidization of buried mass-wasting deposits in lake sediments and its relevance for paleoseismology: Results from a reflection seismic study of lakes Villarrica and Calafquén (South-Central Chile). Sedimentary Geology 213, 121-135.

Moernaut, J., Van Daele, M., Heirman, K., Fontijn, K., Strasser, M., Pino, M., Urrutia, R., De Batist, M., 2014. Lacustrine turbidites as a tool for quantitative earthquake reconstruction: new evidence for a variable rupture mode in South-Central Chile. J. of Geophysical Research, doi: 10.1002/2013JB010738.

Monecke, K., Anselmetti, F.S., Becker, A., Sturm, M., Giardini, D., 2004. Signature of historic earthquakes in lake sediments in Central Switzerland. Tectonophysics 394, 21-40.

Monecke, K., Anselmetti, F.S., Becker, A., Schnellmann, M., Sturm, M., Giardini, D., 2006. Earthquake-induced deformation structures in lake deposits: a late Pleistocene to Holocene Paleoseismic record for Central Switzerland. Eclogae Geologicae Helvetiae 99, 343-362.

Moretti, M., Sabato, L., 2007. Recognition of trigger mechanisms for soft-sediment deformation in the Pleistocene lacustrine deposits of the Sant'Arcangelo Basin (southern Italy): seismic shock vs. overloading. Sedimentary Geology 196, 31-45.

Nelson, A., Sawai, Y., Jennings, A., Bradley, L.A., Gerson, L., Sherrod, B., Sabean, J., Horton, B., 2008. Great earthquake paleogeodesy and tsunamis of the past 2000 years at Alsea Bay, central Oregon coast, USA, Quaternary Science Reviews 27(7-8), 747-768.

Reilinger, R., McClusky, S., Vernant, P., Lawrence, S., Ergintav, S., Cakmak, R., Ozener, H., Kadirov, F., Guliev, I., Stepanyan, R., Nadariya, M., Hahubia, G., Mahmoud, S., Sakr, K., ArRajehi, A., Paradissis, D., AlAydrus, A., Prilepin, M., Guseva, T., Evren, E., Dmitrotsa, A., Filikov, S.V., Gomez, F., Al-Ghazzi, R., Karam, G., 2006. GPS constraints on continental deformation in the Africa-Arabia-Eurasia continental collision zone and implications for the dynamics of plate interactions. Journal of Geophysical Research 111, B05411, doi:10.1029/2005JB004051.

Reimer P. J. and 29 authors, 2013. IntCal13 and Marine13 radiocarbon age calibration curves, 0-50,000 years cal BP. Radiocarbon 55(4), 1869-1887.

Schmidt, S., Howa, H., Diallo, A., Martín, J., Cremer, M., Duros, P., Fontanier, Ch., Deflandre, B., Metzger, E., Mulder, Th., 2014. Recent sediment transport and deposition in the Cap-Ferret Canyon, South-East margin of Bay of Biscay. Deep Sea Research II, http://dx.doi.org/10.1016/j.dsr2.2013.06.004.

Schnellmann, M., Anselmetti, F.S., Giardini, D., McKenzie, J.A., 2006. 15,000 Years of mass-movement history in Lake Lucerne: Implications for seismic and tsunami hazards. Eclogae geol. Helv. 99, 409-428.

Seilacher, A., 1969. Fault-graded beds interpreted as seismites. Sedimentology 13, 155-159.

Şengör, A.M.C., Tüysüz, O., İmren, C., Sakınç, M., Eyidoğan, H., Görür, N., Le Pichon, X., Rangin, C., 2005. The North Anatolian Fault: A new look. Annual Review of Earth and Planetary Sciences 33, 37-112.

Shennan, I., Hamilton, S., 2006. Coseismic and preseismic subsidence associated with great earthquakes in Alaska. Quaternary Science Reviews 25(1-2), 1-8.

Siegenthaler, C., Finger, W., Kelts, K., Wang, S., 1987. Earthquake and seiche deposits in Lake Lucerne, Switzerland. Eclogae Geol. Helv. 80, 241-260. 
Sims, J.D., 1973. Earthquake-induced structures in sediments of Van Norman Lake, San Fernando, California. Science 182, 161-163.

Vologina, E.G., Kalugin, I.A., Osukhovskaya, Yu.N., Sturm, M., Ignatova, N.V., Radziminovich, Ya.B., Dar'in, A.V., Kuz'min, M.I., 2010. Sedimentation in Proval Bay (Lake Baikal) after earthquake-induced subsidence of part of the Selenga River delta. Russian Geology and Geophysics 51, 1275-1284.

Waldmann, N., Anselmetti, F.S., Ariztegui, D., Austin Jr., J.A., Pirouz, M., Moyz, C.M., Dunbark, R., 2011. Holocene mass-wasting events in Lago Fagnano, Tierra del Fuego $\left(54^{\circ} \mathrm{S}\right)$ : implications for paleoseismicity of the Magallanes-Fagnano transform fault. Basin Research 23, 171-190.

Yeats, R.S., Prentice, C.S., 1996. Introduction to special section: Paleoseismology. Journal of Geophysical Research 101, 5847-5853. 